\title{
François Quesnay, Luigi Pasinetti and the Historical Contexts of Economic Theory
}

\section{Professor D'Maris Coffman}

\section{Director, The Bartlett School of Construction and Project Management (BSCPM), UCL, 1-19 Torrington Place, London, WC13 7HB}

\author{
Visiting Professor, Department of Economics, Management and Quantitative Methods \\ (DEMM), University of Milan, Via Conservatorio 7 - 20122 Milan
}

\begin{abstract}
In 2002, Professor Luigi L. Pasinetti gave a keynote address at the Raffaele Mattioli Foundation and Library in honour of their acquisition of a rare third edition of François Quesnay's Tableau Économique. This lecture subsequently appeared as a chapter in Italian in the conference volume edited by Giancarlo De Vivo in 2009. In honour of Luigi Pasinetti's $90^{\text {th }}$ birthday, Professor Coffman has offered the first English translation of Pasinetti's essay on Quesnay, which she also introduces by reflecting on its rhetorical strategy, argumentative structure, and Pasinetti's use of Quesnay to critique mainstream neoclassical economics. She ends her introduction by drawing attention to the place of the Tableau within contemporary debates about taxation and the optimal scale and capacities of the state.
\end{abstract}

\section{Acknowledgements}

The author would like to thank Professor Michelle Baddeley and Professor Roberto Scazzieri for including an early version of this paper in 'The Economics of Structural Change: Theory, Institutions and Policy - A Conference in Honour of Luigi L. Pasinetti' at Gonville and Caius College, Cambridge, 12-13 September 2012. That conference was sponsored in large measure by the Cambridge Journal of Economics. She would also like to thank Dott.ssa Leonarda Martino for assisting her with obtaining copies of relevant chapters in the bibliography which otherwise would have been inaccessible during the Covid-19 pandemic. A warm thank you is also owing to her doctoral student, Mr Kehan He, for swiftly redrawing Figures 3-6 in the English translation of Pasinetti's essay. Finally, she would like to thank Professor Ghislain Deleplace for asking thought-provoking questions during the conference, to Professor Roberto Scazzieri for his thoughtful suggestions and feedback on various drafts, and to Dr Ivano Cardinale for their work together on their 2014 article in Economia Politica which explores intersectoral interdependencies and the political economy of taxation in eighteenthcentury France and Britain. 


\section{François Quesnay, Luigi Pasinetti and the Historical Contexts of Economic Theory}

One of the many striking features of Luigi Pasinetti's theoretical work is his commitment to locating his theoretical stances within the twin histories of economic thought and economic analysis. Pasinetti has repeatedly insisted that his own contributions to what we now think of as input-output analysis, as developed by Wassily Leontief, were made in the spirit of François Quesnay's Tableau Économique. Pasinetti highlights Quesnay's emphasis on understanding a national economy's wealth as in terms of the value of the flow of exchanges (rather than the value of the stock of accumulated wealth or crown treasure) as especially important to the development of his own thinking. For Pasinetti, Quesnay offered ammunition for his sustained attack on the Marginalists (Pasinetti, 2012), while also potentially prefiguring Ricardo's more fully elaborated model of circular flows. ${ }^{1}$

Given the importance of Quesnay to Pasinetti's work, offering the first English translation of his difficult-to-obtain essay on the Tableau Économique seems a fitting way to celebrate Luigi Pasinetti's ninetieth birthday. The original work in Italian, which was given as a keynote address in 2002 at a conference in Milan celebrating the acquisition by the Fondazione Raffaele Mattioli (Raffaele Mattioli Foundation and Library) of a scarce third edition of the Tableau, was eventually published in a conference volume by the Foundation. It is hoped that by offering this translation, we will make this essay available to Pasinetti's wider readership. ${ }^{2}$

In elegant language (which the translator has attempted to capture in English), Pasinetti skillfully employs in his essay a rhetorical device known to students of Cicero as a paralipsis to suggest that while it might be an exaggeration to claim that Quesnay's Tableau anticipated the Keynesian multiplier, a close reading of the text could support the conclusion that Quesnay's work had launched a revolution in economics which, if taken seriously today, would represent a wholesale repudiation of mainstream neoclassical economics circa 2002.

How does Pasinetti reach that conclusion? After a brief introduction and rehearsal of the bibliographic material, Pasinetti describes the eighteenth-century French context for the Tableau, and then explains the operation of the Tableau both in diagrammatic form and as an input-output table. He then outlines the three major theoretical advances he sees in the Tableau followed by four or five additional propositions which derive secondarily from Quesnay's formulations. These are worth rehearsing here.

In Pasinetti's reading of Quesnay, there are three primary postulates: (a) that the 'net product' (produit net) of a nation lies in the surplus of physical goods produced in the primary sector (agriculture) which are above and beyond those consumed in the manufacturing processes of the secondary sectors; (b) that economic activity is a circular process, which, in addition to producing a surplus, supplies all the goods consumed in production, such that the production process may continue unchanged by this flow, though in this process manufacturing creates those goods consumed by the aristocratic class in the forms of necessaries, luxuries, culture,

\footnotetext{
${ }^{1}$ In the January 2012 Clare Hall seminar, Pasinetti suggested that Marquis de Mirabeau's ambiguous reading of Quesnay about how to reflect simultaneously both stock and flow relationships in the Tableau appeared to anticipate subsequent understandings expressed by David Ricardo as reconstructed by Piero Sraffa.

${ }^{2}$ The essay has been translated from Italian to English by D'Maris Coffman, originally in 2012, as a supplement to the following conference paper: "Luigi Pasinetti, Quesnay, Mirabeau and the early modern fiscal state." Presented at "The Economics of Structural Change: Theory, Institutions and Policies: A conference in honour of Luigi L. Pasinetti," Gonville and Caius College, 12-13 September 2012. Coffman has recently polished her translation for publication in 2020. Figures 3-6 therein have been redrawn by Kehan He, who is a doctoral student at UCL.
} 
and military expenditure; (c) the creation of two time horizons, one finite (which is conventional) and one infinite (which is natural). Although Pasinetti's concise statement of these principles is helpful, this particular reading of Quesnay is uncontroversial and should be familiar to students of economic thought.

The secondary postulates, however, are less straightforward if considerably more important. Pasinetti identifies five of them: i) the concept of capital kept in anticipation of the beginning of the next production period, which is held to be the purpose of savings; ii) the formal construction of cash flows and the flows of physical goods as symmetrical to each other, which then also implies that 'money' serves both as a means of payment and as the unit of account; iii) the close relationship between economic constraints and environmental constraints, i.e. that in the eighteenth century, the productive wealth of a nation was formally limited by the potential natural produce of land; iv) the theoretical problem of rents, and of how rents are formally justified as a category of income, as well as the existence of intellectual property (patents and copyrights) and of related transferrable property rights; v) the epistemological status of the relationship between economic theory and economic policy, which in the Tableau can be seen as giving the economist the reality with which available analytical tools must grapple.

In the two concluding sections, Pasinetti argues that structural economists, who work at intermediate levels of aggregation, including production theorists like himself, are the true heirs to the Physiocrats, and that mainstream neo-classical economics (i.e. his opponents, the Marginalists), and modern micro-founded macroeconomics in particular, are 'prephysiocratic' because they focus upon the 'exchange process' by putting the general equilibrium model at the centre of their analysis. Pasinetti argues that this focus on scarcity, on the centrality of the market price mechanism, and on individual economic agents primarily as consumers, harkens back to the Mercantilists, and represents a focus on stocks rather than flows in the economy. For Pasinetti, the Physiocrats focused on the reproducibility (and circularity) of the economic system, in a manner that was especially important to understanding early modern economies on the cusp of industrialisation.

Pasinetti also apprehends that the Physiocrats were essentially Deists, who saw a natural order in what today we recognise as economics as well as in what today we call the life sciences and natural sciences. The Physiocrats, and perhaps also Luigi Pasinetti himself, believed the proper purpose of economic policymaking was to encourage society to configure itself in harmony with the natural order and the natural world, which are believed to be independent of the experiences and preferences of individuals. Pasinetti deftly positions this reading of Quesnay both as anti-constructivist and as a critique of Hayekian methodological individualism, as well as a refutation of the notion of a representative agent (with or without stable preferences) in micro-founded macroeconomics. In effect, Pasinetti depicts Quesnay as the forefather of structuralism in economics and the founder of a strain of economics which focuses attention on production rather than consumption. This is why he believes Quesnay to be truly revolutionary.

There is, however, something we can add to Pasinetti's account. He begins his keynote with an epigram from Schumpeter (1954, p. 6), which Pasinetti positions as an injunction to understand the immediate contexts for economic ideas. What is missing from Pasinetti's account of Quesnay's Tableau was its intended contribution to debates about taxation, particularly the optimal mix between indirect and direct taxation (Cardinale and Coffman, 2014). Unpicking these issues may help readers understand the implications for economic policymaking of the distinction Pasinetti makes between his own followers and those of modern neoclassical economics.

First, it is important to return to the manner in which Quesnay identifies social classes with their economic activities (famously taken up by everyone from Smith to Marx): the 
productive class (agricultural producers and those engaged in mining), the 'sterile class' (artisans and manufacturers who simply work with the material supplied by the first) and the aristocratic class (who own the land and receive the rents), which has the consequence of identifying the aristocratic class with the absolutist state. ${ }^{3}$ In his own elaboration, Pasinetti appears to follow Western rather more than classical Marxism, which saw absolutist monarchy as the outcome of a struggle between the feudal aristocracy and the bourgeoisie. Perry Anderson (1974) contributed a concise summary of this tradition in Lineages of the Absolutist State. Anderson defined absolutism as a 'redeployed and recharged apparatus of feudal domination, designed to clamp the peasant masses back into their traditional social position - despite and against the gains they had won by the commutation of dues.' Contra Marx's formulation, Anderson argues: 'the absolutist state was never an arbiter between the aristocracy and the bourgeoisie, still less an instrument of the nascent bourgeoisie against the aristocracy: it was the new political carapace of a threatened nobility' (Anderson, 1996, p. 18). Taxation, in the Western Marxist tradition, becomes a form of organised rent-seeking with adverse distributional effects.

What the Western Marxist position neglects is the extent to which all early modern states, whether they might be classified as 'absolutist' or 'constitutional', were concerned with how to maximise tax revenues in order to support a king (whether or not he could properly be labelled as the 'first among equals' in a native aristocracy) who could no longer 'live on his own' (i.e. from the income of crown lands), precisely because he was tasked with the external protection of the realm against foreign threats (Coffman 2013). One of the challenges faced by the Physiocrats was how to reform the eighteenth-century French fiscal system (which had languished since the fallout from the collapse of the Mississippi Company in 1721) without inflaming tensions among and between the landowners, their tenants and the commercial and manufacturing classes. In the French case, this was exacerbated by the fact that by midcentury France's position as a global hegemon had come under strain during the Seven Years War (1756-1763).

Both the French Physiocrats and those with whom they corresponded in Britain (including David Hume and Adam Smith) were faced with the problem of how 'to impose taxation in a way that satisfied competing interest groups (land owners, great merchants, and still powerful leading artisans) without damaging the overall productive capacity of the kingdom' (Cardinale and Coffman, 2014, p. 279). There is ample evidence that economic writers in both countries were aware of sectoral interdependencies, and actively engaged with the problem of the legal versus economic incidence of taxation (Cardinale and Coffman, 2014; Einaudi, 1933). In the United Kingdom, the principal preoccupation was the political and economic consequences of the shifting incidence of taxation (which was determined by what we now call price elasticities of demand), particularly in the case of the excise on beer and ale, i.e. 'whether or not the duty would be shifted backwards onto the landowner (in the form of lower prices paid for the agricultural products used in the production of excisable liquors and thus lower rents), forwards onto the consumer (in the form of higher retail prices), or capitalised by the manufacturers' in the form of investment in labour-saving industrial machinery (Cardinale and Coffman 2014, p. 279). Using different analytical tools, William Petty and Charles Davenant undertook analyses of the economic incidence of taxation which are familiar to us today (Cardinale and Coffman 2014; Coffman 2013; Hicks, 1968; Seligman, 1899).

In Britain, the emphasis (as it had been since the seventeenth century where the terms of the debate were drawn by those whom Pasinetti labels Mercantilists) was on the market price

\footnotetext{
${ }^{3}$ In contrast to classical political economists (from Smith to Marx), Quesnay mainly associates social classes with economic sectors (primary and secondary) and industries (e.g. agriculture, mining, artisans, manufacturing, officeholders, the military, etc) rather than with sources of income (wages, profits, rents).
} 
mechanism: how might an indirect tax raise or lower prices paid for raw materials, intermediate goods and finished products, and who would bear the costs. Ultimately, this debate was resolved in the British tradition in favour of the cost of the excise ultimately falling on wages (Seligman 1899). In France, the Physiocrats, following Quesnay, would arrive at the idea that the 'impôt unique' (which was a tax on agricultural produce) was the optimal tax, because it taxed the net product of the land, leaving industry and commerce free from taxation.

In France, what Quesnay most immediately offered his contemporaries was a novel theory of taxation and an analytical model for tax incidence that was compatible with absolute monarchy (Einaudi 1933; Tsoulfidis 1989; Pressman 1994; Visine, 1955). As Einaudi (1933) explains, the Physiocrats, while acknowledging the potential for the shifting incidence of taxation to incite sectoral conflicts, were primarily concerned with the loss in national income due to transaction costs (particularly from tax farming) that such activity incurred (Einaudi, 1933, pp. 130-132). If the Physiocrats' British interlocutors were chiefly concerned that tax policies be constructed in such a way as to avoid upending systemic interests and sectoral interdependencies, the Physiocrats were concerned with building state fiscal capacity. As Einaudi explains, this was because the Physiocrats believed that 'the proper object of the tax is that part of the national dividend which is the necessary remuneration of the political class,' while at the same time recognising that "the "free" part of the national dividend cannot be entirely appropriated by the State' (Einaudi, 1933, pp. 131-133). The Physiocrats were as much concerned with the problem of the optimal size and composition of the state (the balance between and among tax farmers, salaried officials and noble and aristocratic officeholders) as they were with how to reform taxation (Einaudi, 1933, p. 133). The appropriate scale, scope and limits of state power in both legal and fiscal terms remains a hotly debated issue today.

It is perhaps no surprise then that mainstream economics still regards tax policy as creating the optimal mix of direct (income, capital gains) and indirect (excise, value-added duties) taxes in order to maximise short-run incentives to productivity, whereas followers of Quesnay and Pasinetti would argue society should tax the rentiers. In practice, taxing rents means taxing 'surplus' wealth, which means taxing stocks, where modern macroeconomics relies upon taxing flows. This returns us to problem of how to separate the state from the rentiers, or put it differently, the problem of how to conceptualise, both theoretically and practically (in order to avoid capture), the modern state (in contrast to the early modern absolute monarchy) within the economic system. Modern critics of mainstream economics, including those like Mariana Mazzucato (2018) and Thomas Piketty (2014), might well find much to applaud in Luigi Pasinetti's reading of Quesnay. 


\section{Bibliography}

Anderson, P., 1974. Lineages of the Absolutist State. London: New Left Books.

Cardinale, I. and Coffman, D., 2014. Economic interdependencies and political conflict: The political economy of taxation in eighteenth century Britain. Economia politica, 31(3), pp. 277-300.

Coffman, D., 2012. 'Luigi Pasinetti, Quesnay, Mirabeau and the early modern fiscal state.' Unpublished conference paper presented at "The Economics of Structural Change: Theory, Institutions and Policies: A conference in honour of Luigi L. Pasinetti,' Gonville and Caius College, 12-13 September 2012.

Coffman, D., 2013. Excise taxation and the origins of public debt. Basingstoke: Palgrave Macmillan. https://doi.org/10.1057/9781137371553

Einaudi, L., 1933. 'The Physiocratic Doctrine of Taxation,' in Economic Essays in Honour of Gustav Cassel. London: Allen and Unwin, pp. 129-142.

Hicks, U.K., 1968. Public Finance. Welwyn: J. Nisbet. 3ed.

Mazzucato, M., 2018. The value of everything: Making and taking in the global economy. London: Penguin.

Pasinetti, L.L., 2012. 'A Conversation with Luigi L. Pasinetti,' Cambridge Seminar in the History of Economic Analysis at Clare Hall, 19 January, 8.15 p.m.

Pasinetti, L.L., 2009. 'Il Tableau Économique e le economie 6conom,' in Giancarlo De Vivo (ed.), Il Tableau économique di François Quesnay, with contributions by Vieri Becagli, Giorgio Gilibert and Luigi Pasinetti and an introduction by G. de Vivo. Milan: Fondazione Raffaele Mattioli per la storia del pensiero 6conomic, pp. 109-24.

Piketty, T., 2014. Capital in the 21 Century. Trans. Arthur Goldhammer. Belknap Press. https://doi.org/10.4159/9780674982918

Pressman, S., 1994. 'Quesnay's Theory of Taxation. $\backslash$ Journal of the History of Economic Thought, 16(1), 86-105. https://doi.org/10.1017/S1053837200001437

Seligman, E.R.A., 1899. The Shifting Incidence of Taxation. New York: Augustus M. Kelley [1969].

Tsoulfidis, L., 1989. 'The physiocratic theory of tax incidence.' Scottish Journal of Political Economy, 36(3), pp. 301-310. https://doi.org/10.1111/j.1467-9485.1989.tb01094.x

Visine, F. 'L'impot Unique des Physiocrates a Eugène Schueller.' Revue d'économie politique 65, no. 3 (1955): 409-26. 


\title{
Appendix One: The English Translation
}

\author{
The Tableau Économique and the Modern Economy
}

Luigi Pasinetti

\section{Premise}

The acquisition, on the part of the 'Raffaele Mattioli' Library, of a copy of the very rare third edition of the Tableau Économique by François Quesnay is such an extraordinary event as to kindle the most daring flights of fancy. I wonder, for example, how Raffaele Mattioli, who had dreamed of owning this document, would have celebrated this moment. Perhaps he would have been pleased to recall the famous words of Quesnay's principal disciple, Victor Riqueti, the Marquis de Mirabeau (also cited by Adam Smith, in Wealth of Nations,[1776], 1902, vol. II, p. 177), according to whom in world history there have been three great inventions 'that principally lent stability to political societies' and 'these are the invention of writing [...], the invention of money [...] and the Tableau Économique.'

Extravagant claims? Perhaps. But do not come to that conclusion before devoting some close attention to this text, with the aim of investigating its relevance, not so much (or at least not only) to bibliophiles, but also, and above all, as a contribution to our understanding of our modern economic age.

\section{The Mattioli Foundation's copy - some essential historical details}

The document acquired by the Mattioli Library is, as we know, a 38-page booklet, printed at the Court of King Louis XV, in early 1759, as has already been recounted by de Vivo, Gilibert, and Becagli. It consists of the famous Table, based on 600 (i.e. 600 million French lire of the time), an 'Explication' of the Table itself (12 pages), and an 'Extract from the Économies Royales of M. de Sully (22 pages).

The Table appearing in the Foundation's copy is reproduced below as Figure 1. To the eyes of twenty-first century economists, the Table may appear a little cumbersome, with all these zigzag dotted lines - as commonly described - through which the author intends to reconstruct the various flows of goods in the exchanges between the various social classes. Some modern economists have even perceived the analytical origins of a Keynesian multiplier in the zigzag network. But we will not make such assumptions. Instead we will make less speculative claims in favour of exploring the more immediate meanings of the text.

[Insert Figure 1 here]

To begin, it is important to remember that three copies of this document, known as the third and in some ways definitive edition of the Tableau, are currently known to survive, all of which have only recently come to light, after having been taken for lost or destroyed, only to be found and then lost again, and finally now safely recovered.

The first copy was discovered in 1965 by the Polish Economist Marguerite Kuczynsky, after her investigation as archivist-detective, into the papers of the heirs of the Dupont de Nemours family, at the Eleutherian Mills Historical Library in Delaware, USA. ${ }^{4}$ A second copy was offered for sale by an antiquarian bookseller in Berlin a few years later and was purchased by

\footnotetext{
${ }^{4}$ Translator's note: the Eleutherian Mills Historical Library was renamed the Hagely Museum and Library in 1984 and is a major resource for business historians.
} 
the Nihon University Library in Tokyo, Japan. Finally, a third copy was discovered by Vieri Becagli, as Becagli (1971) himself describes, at the Gozzini antiquarian bookshop in Florence in 1970. This is precisely the copy which was purchased by the Mattioli Foundation Library and is located here in the place where we are gathered.

As this is the third edition (1759), there are evidently two previous editions. The second edition in print is from late 1758 or early 1759. It is that edition that became known through the facsimile publication in 1894 by the British Economic Association. As with the third edition, it uses 600 [million lire] as the base. We know that this copy exists in the original at the French National Archives in Paris. But there is another copy in Paris at the Bibliothèque nationale de France. On the other hand, no print copies of the first edition, which was first discovered in 1858, are known, at least so far. The existing copy [of the first edition], which is also found in the French National Archives, is a manuscript copy handwritten by François Quesnay himself. Contrary to successive editions, it uses 400 [million lire] as the base.

In the 1760s, Quesnay's disciples published three more editions until François Quesnay himself presented a detailed version of them in an article in the Journal de l'Agricolture, $d u$ Commerce e des Finances, of 1766. Quesnay expanded hid Tableau using 2,000 million French lire as the base. The text is very detailed (consisting of 41 pages in all) with an 'Analysis of the Arithmetic Formula'. However, nowhere in the entire article is there a graphic representation in the form of a Table. This is the last publication that François Quesnay, who died in 1774, dedicated to his famous Tableau.

But [Quesnay's] disciple, [Pierre Samuel] du Pont de Nemours (1767) took up precisely this version, with 2000 as the base, in the following year, publishing a detailed summary in Physiocratie (of which the Mattioli Foundation's Library also possesses an original edition) and giving an explicit rendering in tabular form, using 2000 as a base, as described by Quesnay. ${ }^{5}$ It is reproduced here as Figure 2.

[insert Figure 2]

This is a Table of the same construction as the first three (i.e. zig-zagged), but more concise and more complete in the accompanying notes. All subsequent scholarly literature has referred to the magnitudes that appear in this version of the Tableau Économique. And so shall we.

\section{The Physiocratic Scheme of a society based on agricultural production}

To understand François Quesnay's masterpiece, we must travel back in time using our imaginations to picture the predominately agricultural economy that characterized France in the mid-1700s. We find ourselves in a purely authoritarian regime, that of an absolute monarchy; yet we find ourselves at the heart of that extraordinary intellectual movement, so relevant to all of human history (of which Quesnay and his disciples were members), which we know as the French Enlightenment.

Quesnay conceived, with Mercier de La Rivière (1767), of an 'ordre natural et essentiel des sociétés politiques', that is, the fundamental natural order in social interchange, which is the task of the scholar to elaborate and of governments to realize [through policy-making]. Hence the name Physiocracy (i.e. etymologically 'the government of nature') which Quesnay and his followers coined for the school of economics which they founded (du Pont de Nemours 1767).

\footnotetext{
${ }^{5}$ Translator's note: in full, the title is Physiocratie, Ou Constitution Naturelle du Gouvernement le Plus Avantageux au Genre Humain.
} 
The schematic presented by Quesnay is very simple. In it there is first an identification of social classes in terms of the economic activities they perform (the further identification of which will be taken up and further developed by classical economists and by Marx).

Members of society are grouped into three classes, each of which has particular rights or performs particular functions: the productive class, the so-called 'sterile' class, and the proprietary (landed) or aristocratic class. The 'productive class' consists of those involved in agriculture and mining. This denotation derives from the fact that this class works the land, obtaining from it a physical quantity of economic goods (foodstuffs) that - as appears from completely objective and concrete evidence - is greater than the physical quantity of the same goods used initially as raw materials. Thus, land is considered to be the only factor capable of giving a 'net product'. The 'sterile class' consists of artisans and manufactures. It is so called because, in Quesnay's conception, this class does not add anything to the 'net product'; it simply 'transforms' what is produced by the productive class. Finally, the 'aristocratic class' consists of the King, and the noble and the ecclesiastical landowners. This class owns the land and receives income from the land so owned.

In such a social structure, it is self-evidently necessary that 'exchanges', that is, flows of material goods from one class to another, must take place in order that the wealth produced is distributed among the various classes of society. What the Tableau Économique proposes to do is precisely to represent these exchanges. The arithmetic formula originally employed by Quesnay to calculate these exchanges is cumbersome and today only of historical interest. But then today, we have at least two alternative methods of giving the Table a more effective, and in our eyes, more faithful presentation.

\section{The Tableau Économique in diagrammatic representation}

A representation of Quesnay's Tableau Économique that has proven very successful for the purposes of teaching is the one devised by the Japanese economist Shigeto Tsuru (1942) and adopted by Paul Sweezy (1951). I also used it in my own textbook on production theory (Pasinetti 1989), from whence I will now borrow extensively.

Let us suppose that the production process occurs during a finite period of time (which we can call a year) and that all exchanges take place at the end of that period. Quesnay's Tableau could be represented as depicted in Figures 3 and 4, which refer respectively to the condition of the economic system before the exchanges and after the exchanges.

[insert Figure 3 and Figure 4 here]

Figure 3 shows the series of goods (or values) that each class obtains at the end of the production year. Each non-dashed rectangle represents a physical amount of assets worth 1 billion lire. The symbol A indicates agricultural foodstuffs, MP the raw materials, M the manufactured goods. The two thinner and dashed rectangles represent 2 billion lire in currency (i.e. means of exchange, introduced here merely as an accounting convenience). The arrows indicate the exchange flows. More precisely, the dotted arrows represent the monetary flows and the continuous arrows represent the real flows (which are inverse and symmetrical to the former).

Once the exchange process is finished, the situation appears as presented in Figure 4.

The productive class ends up in possession of the 2 billion lire in monetary terms. However, as this represents rents for the use of the land, this reverts to the landowning class at the beginning of the next period. In this manner, the initial conditions are re-established and the production process can resume as before. At the end of the next production period, the same process of the exchange and circulation of economic goods will repeat itself in exactly the 
same way as in the previous year. The landowning class thus is able to obtain at the end of each period not only the replenishment of its monetary reserves, but also real goods valued at 2 billion lire. These 2 billion lire of goods constitute precisely the physical surplus over what is necessarily required by the economic system as a whole to keep the production process constant over time. This represents for Quesnay the 'net product' (produit nuit) of society.

As we can see, Quesnay's scheme is of such simplicity that in our eyes it can even appear primitive. Yet to find a superior scheme for depicting industrial interdependencies, we must look to the present, or rather to the publication of the twentieth-century masterpiece by Wassily Leontief, who in 1941 began his book, The Structure of the American Economy with the words: 'The statistical study presented in the following pages can be best understood as an attempt to build, on the basis of statistical material, a Tableau Économique of the United States of America from 1919 to 1929' (Leontief 1941, p. 10).

\section{The Tableau Économique as an input-output representation}

Leontief's definition of his own work as a modern Tableau is indeed apt. If we examine the scheme represented above, we realize that it is in fact a scheme of industrial interdependencies found in a stationary economic system. The concepts expressed thus far can therefore also be represented in an alternative fashion by applying the tools provided by Wassily Leontief, that is, by inserting the flows originally considered by Quesnay into a double-entry table. This was first attempted by Almarin Phillip (1955) and is-with some rearrangements - what is proposed here in the Table that appears in Figure 5.

\section{[insert Figure 5]}

If we accept the identification - made by Quesnay—of social classes with their forms of economic activity, Figure 5 appears as a real Leontievian input-output table capable of faithfully translating into input-output flows the simplified scheme described in the previous section. The productive and 'sterile' classes (first two rows and columns) represent what we now call the inter-industrial part of the Table, while the aristocratic class (3rd row and 3rd column) represents the 'final sector'. The surplus or net product of the economic system which in Quesnay's conception goes entirely to the landowning class, that is, to the rentiers can be interpreted in two different ways. In the third column it appears as the set of material goods available to the final sector; and, in the third line, it appears in terms of its other aspect, that of its 'value-added' to the means of production.

In rewriting this Table, it was necessary to add some important glosses. The result is Figure 6, which explains the composition of the Tableau Économique using modern terminology, freeing it from the cumbersome zigzag lines and rendering it accessible to our own customs and methods of double-entry accounting. The text circled with dashed lines provides typical classifications of input-output analysis and modern national accounts.

\section{[insert Figure 6]}

We are now able to understand how we can see in Quesnay's Tableau startling anticipations of many of the concepts that were subsequently developed by economic theory as we are familiar with it today.

\section{The theoretical anticipations of the Tableau Économique}

First of all, we can see clearly emerging from Quesnay's Tableau Économique at least three ideas that are consistently found in subsequent economic literature. 
a) The idea of a surplus or 'net product' (produit net), that is, of a physical surplus of goods produced over goods that must be used in the production process. In Quesnay's scheme, this net product originates entirely in the primary sector, where it can be objectively observed that at the beginning of the year, goods valued 3 billion lire physically enter, and at the end of the same year 5 billion are returned.

b) The idea of economic activity as a circular process which, in addition to producing a surplus, reproduces all the material goods consumed in the production process in a given period, so that the production process can proceed unchanged in the following period. Notice how this circular process is essential to Quesnay's very conception of his entire analytic scheme. In fact, primary sector goods (food and raw materials) are needed to fuel the production process of the products and at the same time the products are needed to fuel the production process of the primary goods. ${ }^{6}$ In Piero Sraffa's terminology, we would say that today both primary goods and manufactured goods are 'basic goods' while 'non-basic' goods are goods that are purchased by the aristocratic (landed) class (luxury, cultural and military goods). For Quesnay, it is the latter who ultimately consume the net product of the entire economic system. In fact, the physical surplus of goods originated in the primary sector but was transformed by the interaction of the primary sector with the secondary (manufacturing) sectoronly to emerge in the form of the goods valued at 2 billion that the aristocratic class chooses to consume.

c) The concept, which is purely analytical and notional, of dividing time into finite periods, such the production process and all the activities technically required by it take place during each period. At the end of each period, exactly at the point which separates it from the subsequent period, the analysis pauses, so to speak, to take account of the set of exchanges that take place. These exchanges are necessary for the entire economic system to make the 'net product' available to the aristocratic class, thereby resetting the initial condition through which it is possible to start the production process again from scratch in the following period.

But this is not all. We can see in Quesnay's Tableau - even if not as explicitly as it is for the three notions mentioned above - a whole series of other important concepts that have been enunciated, clarified (and in some cases not yet clarified, though addressed and developed) by practitioners of economic analysis over the centuries that followed. I will mention some of the most relevant:

i) The concept of capital as anticipation, that is as necessary as a means of production, which must be regularly present in an economic system (and here the function of the 'saving' classes emerges) and available, to be combined with labour, before it begins the productive process. This concept soon becomes foundational to the schemes of classical economists and will become an essential aspect of the theory of capital [found in Marx and others].

ii) The contra-position of monetary flows and the flows of physical goods produced in the economic system; the one is symmetrical to the other. Until this point, money had mainly been considered for its intrinsic value. With the Tableau, money also becomes relevant as a unit of account and as a means of payment. In effect, this opens a door, which will be fully explored only in the decades that followed, to a conception of money as a conventional and fiduciary unit of measure to facilitate exchange (e.g. in paper money).

iii) The close relationship between economic and environmental constraints. One of the

\footnotetext{
${ }^{6}$ Translator's note: in this scheme, the produce of the primary sector (the productive class) literally feeds the labourers of the productive and sterile classes, and also furnishes raw materials for manufacturing, while much of the produce of the secondary sector (the sterile class) is directed to equipping the productive class.
} 
central premises of the Tableau is the notion that the productivity of the economic system is closely linked to the land - the environmental resource par excellence. In the two centuries following the publication of the Tableau, industrial economies have been able to reduce this dependence to a considerable degree, but in recent decades, as we all know, the relationship between economic development and environmental sustainability has once again become a hot topic.

iv) The problem of rent in an economic system. The existence of non-reproducible goods and related property rights raises the question of whether rent is justified as an income category. In the Tableau, land ownership and rental income associated with it are taken as assumed from the outset. But in the intervening two centuries, such rents will be critically scrutinized and made the subject of endless debates and discussions. Moreover, today the concept of rent has been further elaborated and applied to an entirely new context, that of intellectual property. Legal concepts, such as patents, were introduced precisely with the aim of protecting (it would seem at this stage artificially, given that the legal institution was specifically invented for this purpose) someone who has an idea and wishes to exploit it commercially. We have come very far from the Quesnay's primitive state, in which rents are tied to a single natural and immediately physical resource (the land). But the category of rents and the need for the theoretical justification and legal protection of the rentier remain topics that generate wider discussion. Finally:

v) The challenge of how to combine economic theory and economic policy. Here we can reverse direction. Faced with so much abstract formalism, often detached from reality (and full of simplifying assumptions), so widespread in modern economic literature, the Tableau draws the reader's attention to factual reality. This presentation and interpretation of the Tableau has the precise purpose of generating prescriptions and recommendations of an economic and institutional nature, leveraging the productive capacities of a particular case, the French economy of the mid-1 $18^{\text {th }}$ century, which is analyzed with as yet still primitive analytical tools, but with far-sighted ideas.

And here we could end, having simply taken note of an astonishing list of scientific advances, in theory and in economic policy, which we are able to identify in the toilsome elaborations of a group of eighteenth-century scholars who for the first time described themselves as Les Economistes.

\section{In search of the foundations of modern economics}

Yet something still remains unexplained in this account. We bring to mind the astonishing words of the Marquis de Mirabeau, which impressed so many, beginning with Adam Smith (see section 1). In the face of Mirabeau's declaration, the great majority of modern economists typically offer an ironic smile. But are we sure we understand the meaning? Here, more than elsewhere, it is necessary to recall Schumpeter's injunction to investigate 'how economists have come to think the way they do'. ${ }^{7}$ Are we certain that we truly understand what underpins the Tableau, and more generally the Physiocratic economists' modes of thought?

In fact, if we direct our attention to the fundamentals, it might not be entirely unjustified to describe mainstream economics as even 'pre-physiocratic' in that by putting the general equilibrium model at the center of the analysis, the emphasis is placed essentially on the exchange process, as it was with the Mercantilists before the Physiocrats. This necessarily focuses attention on the characteristics of an economic system associated with this approach: scarcity of resources, uni-directional economic processes, the centrality of the price

\footnotetext{
${ }^{7}$ Translator's note: the version of this essay published by the Mattioli Foundation begins with an epigram from Schumpeter (1959, pp. 6) to which Pasinetti alludes here.
} 
mechanism, and the treatment in economic analysis of the individual as a 'consumer'. All these elements are of secondary importance in the Tableau Économique. Furthermore, the general equilibrium model is essentially tied to a notion of wealth that is very close to that of the Mercantilists, that is, of a static quantity of resources - a stock of inherited goods - to be utilized in an optimal way.

Now the Physiocrats radically broke with this tradition. The wealth of a nation is for them not in a stock, but a flow - the annual net national product — where they focus attention. We could also say, if we were to borrow somewhat crudely Keynesian terminology, that in their mode of analysis, despite all the analytical shortcomings of such a primitive scheme, we can see glimpses of a new paradigm based upon a 'monetary economy of production,' which was the first title given by Keynes to the work he eventually titled The General Theory (Keynes 1936).

In any case, when compared to previous generations, the Tableau really is a great leap forward, a radically new way of perceiving economic realities, a method that places the production process and the reproducibility of the economic system at the center. It thus appears methodologically suited to analyzing the new industrial economies that were emerging throughout eighteenth-century Europe. The greatness of the Tableau lies precisely here: the author, in his brilliant intuition, was able to formulate a fresh approach to understanding economic reality at the very eve of the Industrial Revolution.

\section{A final reflection on the future of economic theory}

Finally, one wonders whether it is possible after two and a half centuries to restore this alternative approach to understanding economic reality to the center of economic theory. In examining this possibility, it is worth recalling another feature of the Tableau already introduced at the beginning of this presentation. The idea of a natural order in the world of economics, as well as in that of physics (and biology) is deeply rooted in Quesnay's work and typical of the physiocratic movement as a whole. They believed it was necessary to encourage society to tend towards this order through the construction of appropriate institutions, but the natural order is itself independent of individual human experiences.

The attraction and in some ways the charm of this concept should not be underestimated when compared to the current state of economic research. By emphasizing the search for objective elements of reality, this approach avoids tying economic hypotheses to human subjectivity (via methodological individualism). Conversely, the Tableau also stands in stark contrast to the method, popular in the dominant theory, of relying upon a representative agent (or single individual) as the point of reference for every economic relationship. More precisely, the assumption of objectivity permits a clear distinction between what is fundamental in economics, and what is the result of individual preferences (subjective, and therefore unstable). This makes it possible to offer a methodology better suited to confronting the social complexity of modern economic systems, without having to revise the underlying assumptions too frequently.

If one day such a methodological orientation contributed to the establishment of a new economic theory centered on production (rather than consumption), there is no doubt that the Tableau would have a good claim to being recognized, if not as an invention revolutionizing the world — as Mirabeau imagined it — certainly as an invention capable of revolutionizing economic theory. 


\section{BIBLIOGRAPHY}

Becagli, Vieri (1971), 'A proposito della prima edizione del «Tableau Économique»', Studi Storici, Istituto Gramsci editore, Anno XII, n. 4, pp. 171-181.

Du Pont, de Nemours (1767), La Physiocratie - ou, constitution naturelle du gouvernement le plus avantageux au genre humain, (a Pekin), Paris: Chez Merlin.

Institut National D'études Démographiques (a cura di) (1958), François Quesnay et la Physiocratie, with Preface by Luigi Einaudi and Presentation by Alfred Sauvy, 2 vols., Paris: Institut National D'études Démographiques (I.N.E.D.).

Keynes, John Maynard (1936), The General Theory of Employment Interest and Money, London: Macmillan; trad. it. Teoria generale dell'occupazione, dell'interesse e della moneta, Torino: Utet, 1971. https://doi.org/10.1007/978-3-319-70344-2

Kuczynski, Marguerite and Meek, Ronald L. (eds.) (1972), Quesnay's Tableau Économique, London: Macmillan and New York: Augustus M. Kelley, by the Royal Economic Society and the American Economic Association. https://doi.org/10.1007/978-1-349-00902-2

Leontief, Wassily (1941), The Structure of American Economy, 1919-1929, Cambridge (Mass.): Harvard University Press.

Mercier, de La Rivière (1767), L'Ordre Naturel et Essentiel des Sociétés Politiques, (London) Paris: Jean Nourse, 2 vols.

Mirabeau, Victor Riqueti, marchese di, (1763) Philosophie rurale, ou l'économie générale et politique de l'agriculture, Amsterdam: Les Libraries Associés.

Pasinetti, Luigi (1989), Lezioni di teoria della produzione, $2^{\text {nd }}$ edition, Bologna: Il Mulino.

Phillip, Almarin (1955), 'The Tableau Économique as a Simple Leontief Model', in The Quarterly Journal of Economics, vol. LXIX, pp.137-144. https://doi.org/10.2307/1884854

Quesnay, François (1766), 'Tableau Économique', in Journal de l'Agriculture, du Commerce et des Finances, Book V, Part III, pp. 3-41.

Quesnay, François (1894 [1758-9]), Tableau oeconomique. - First printed in 1758 and now reproduced in facsimile for the British Economic Association, with Preface by Henry Higgs, London: Macmillan.

Quesnay, François (1965 [1759]), Tableau Économique, republication of the original $3^{\text {rd }}$ edition, edited by Marguerite Kuczynski, Berlin: Akademie-Verlag.

Schumpeter, Joseph A. (1954), History of Economic Analysis, Oxford: Oxford University Press. https://doi.org/10.4324/9780203983911

Smith, Adam (1902 [1776]), An Inquiry into the Nature and Causes of the Wealth of Nations, (edited by) Edwin Cannan, vol. II, London: Methuen and Co.

Sweezy, Paul (1951), La Teoria dello Sviluppo Economico, Turin: Einaudi.

Tsuru, Shigeto (1942), 'On Reproduction Schemes: 1. Quesnay’s Tableau', in Paul M.

Sweezy, The Theory of Capitalist Development, New York: Oxford University Press, pp. 365367; trans. as La Teoria dello Sviluppo Economico, Turin: Einaudi, 1951, pp. 281-284. 


\section{TABLEAU ECONOMIQUE.}

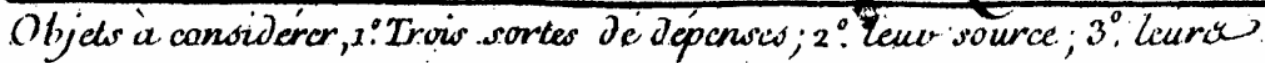
avances; $4^{\circ}$. lewt Jistribution; $5^{\circ}$ leurs effets; 6. lew reproduction; $7^{\circ}$. leurs rapports entr'elles; 8. lims rapporls avec la population; $9^{\circ}$ avec $L^{\prime} \alpha-$ griculture; $10^{\circ}$ avec lindustive; 11 : avec le commerce ; 12 :aveclamasse des richesses: d'une Nation.

$$
\begin{aligned}
& \text { DEPENSES } \\
& \text { PRODUCTIVS } \\
& \text { inclativod' ì } \\
& \text { DEPENSES DU REVENU, }
\end{aligned}
$$

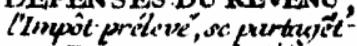

$$
\begin{aligned}
& \text { anx Dipoveres productivin at } \\
& \text { and Dipinases stíriles. } \\
& \text { DE'PENSES } \\
& \text { STERRLES } \\
& \text { ivlutives a }
\end{aligned}
$$

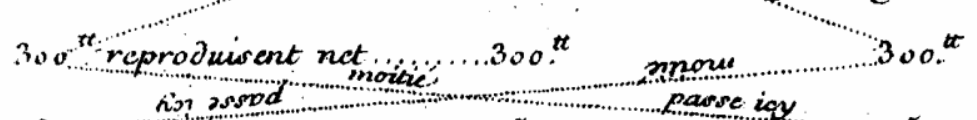

\&tc.

REPRODTTT TOTAL ...............600.. de revenu; de plus, les frais annuels de 600 "t et led interets des avances primitives du Labourcur, de 300 t. que, la terre restitue. Ainai la reproduction est de ${ }^{1500}$. compris Le revenu de 600. qui ist la base Ju calcul, abstraction faitr. Je limpôt préleve', et des avainces qu'erige sa reproduction annuelle, \&ce. Voycx L'Explication à la page suinants.

Figure 1: Quesnay's Tableau (1759) as it appears in the third edition which was acquired by the Raffaele Mattioli Library. 


\section{F O R M U L E \\ Du Tableau économique.}

\section{REproductron totale. Cinq Milliards:}

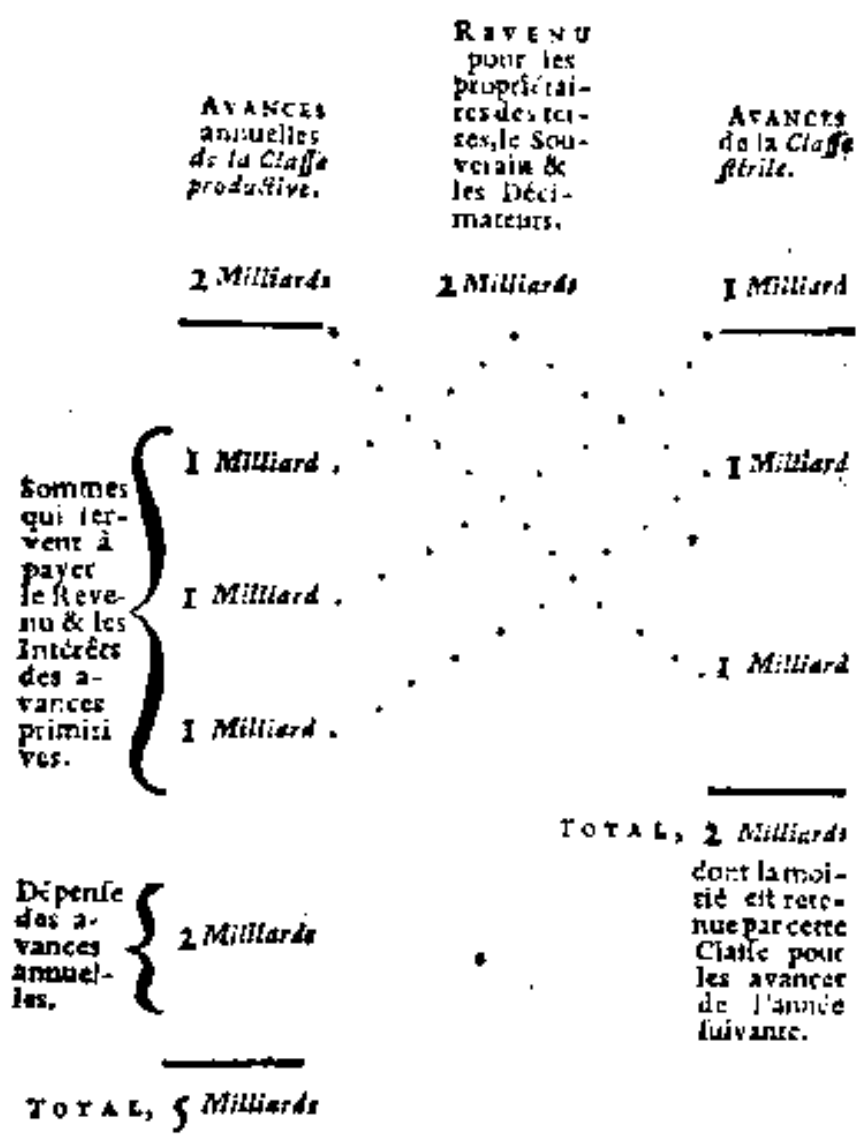

Figure 2: The Tableau as it appears in Dupont de la Nemours (1767), Physiocratie 


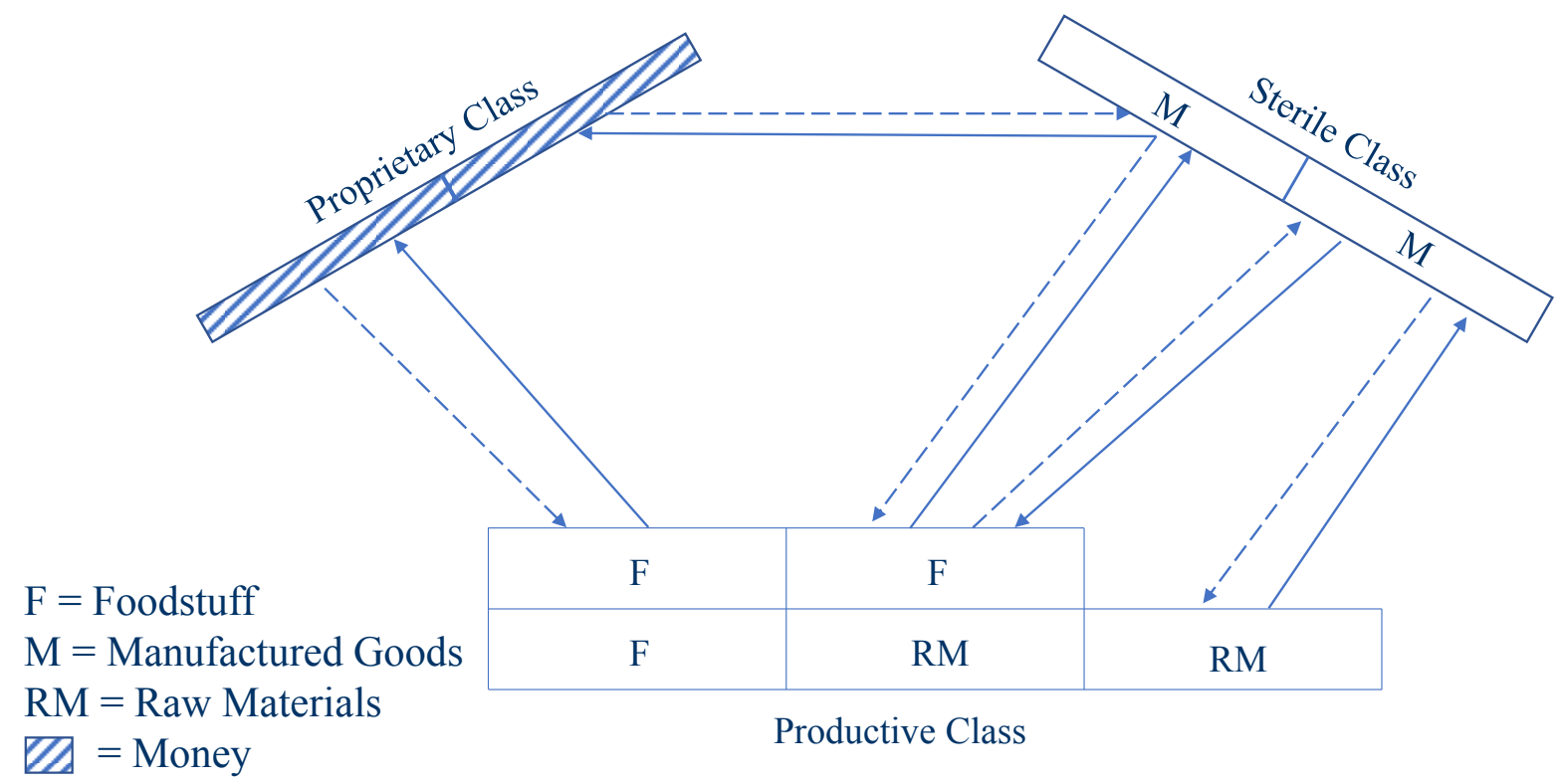

Figure 3: Before the Exchanges
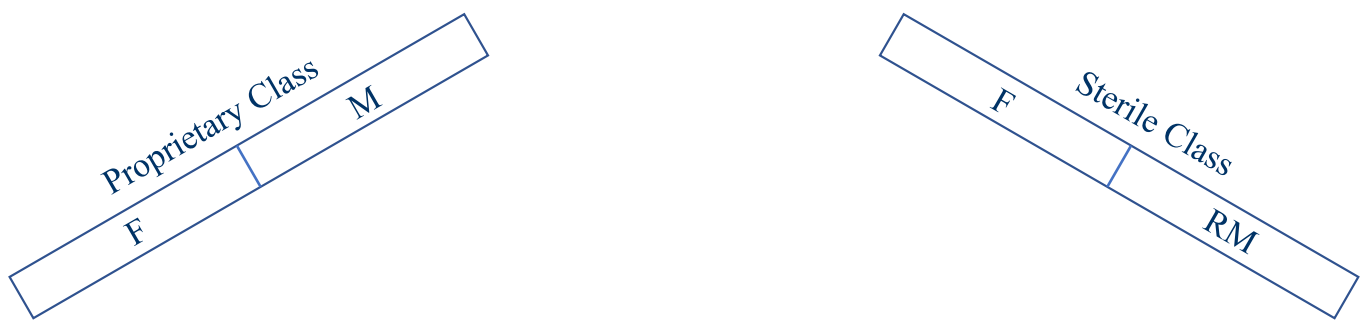

$\mathrm{F}=$ Foodstuff

$\mathrm{M}=$ Manufactured Goods

$\mathrm{RM}=$ Raw Materials

$\mathbb{Z}=$ Money

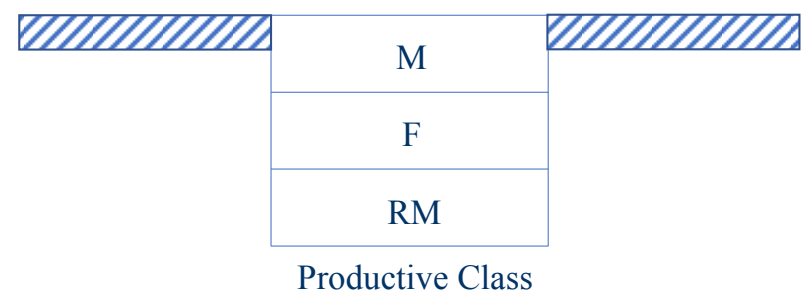

Figure 4: After the Exchanges 


\begin{tabular}{|c|c|c|c|c|c|}
\hline \multicolumn{6}{|c|}{ (in billions of lire) } \\
\hline \multirow[b]{2}{*}{ Input } & & \multicolumn{4}{|c|}{ Output } \\
\hline & & $\begin{array}{l}\text { Productive } \\
\text { Class }\end{array}$ & $\begin{array}{l}\text { Sterile } \\
\text { Class }\end{array}$ & $\begin{array}{l}\text { Proprietary } \\
\text { Class }\end{array}$ & $\begin{array}{l}\text { Grand } \\
\text { Total }\end{array}$ \\
\hline Productive Class & $\begin{array}{l}\text { Foodstuff } \\
\text { Raw Materials }\end{array}$ & $\begin{array}{l}1 \\
1\end{array}$ & $\begin{array}{l}1 \\
1\end{array}$ & $\begin{array}{l}1 \\
-\end{array}$ & 5 \\
\hline Sterile Class & $\begin{array}{l}\text { Artisanal production goods } \\
\text { Luxury Goods }\end{array}$ & $\begin{array}{l}1 \\
-\end{array}$ & $\begin{array}{l}- \\
-\end{array}$ & $\overline{1}$ & 2 \\
\hline Proprietary Class & & 2 & - & - & (2) \\
\hline Grand Total & & 5 & 2 & (2) & 7 \\
\hline
\end{tabular}

Figure 5: The Tableau in the Form of an Input-Output table

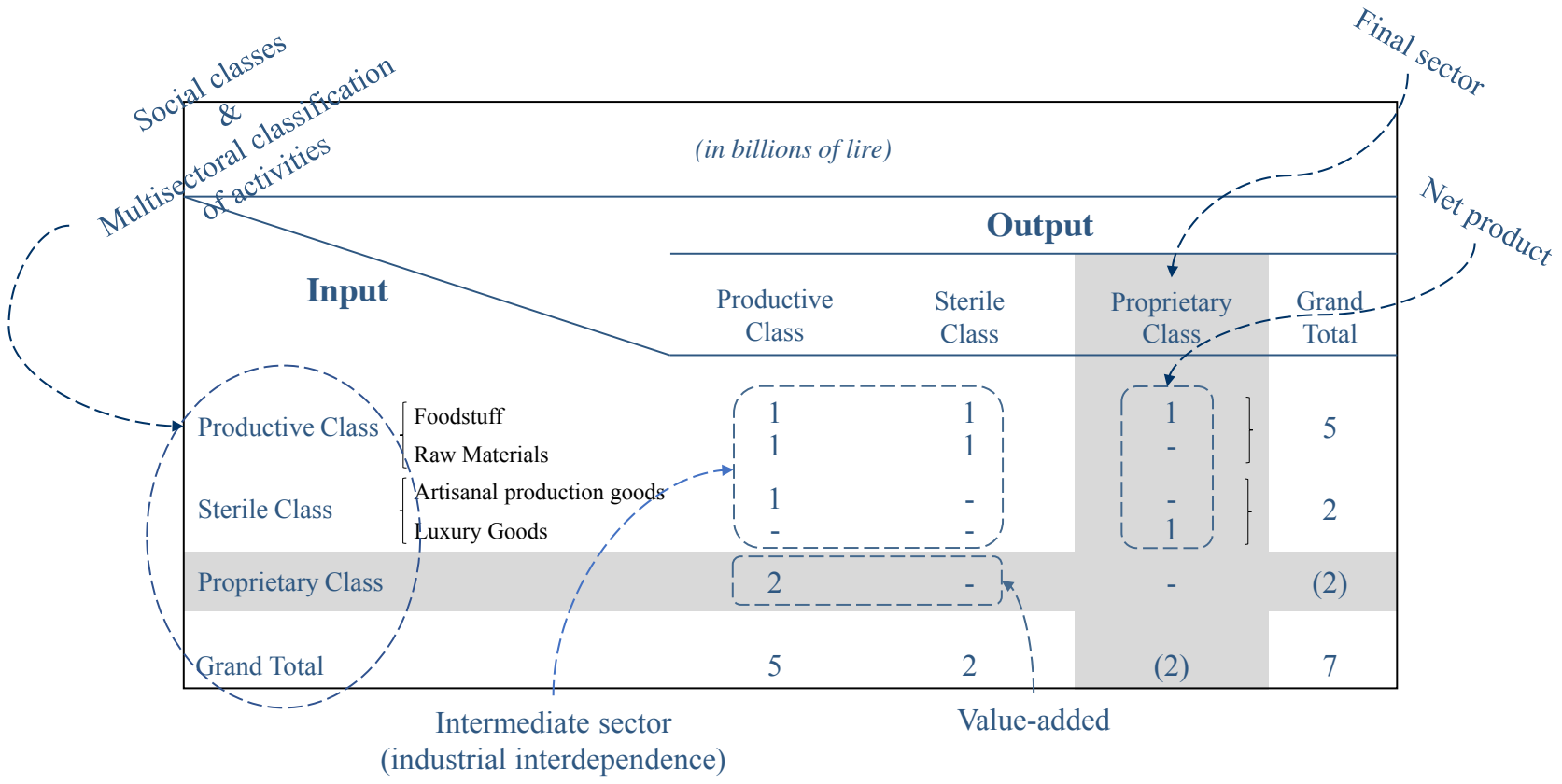

Figure 6: The Tableau in the Form of an Input-Output table with comments 


\begin{abstract}
Author Statement
Professor D'Maris Coffman is the sole author of this manuscript. She has no competing
interests to declare.
Author Statement
Professor D'Maris Coffman is the sole author of this manuscript. She has no competing
interests to declare. Author Statement
Professor D'Maris Coffman is the sole author of this manuscript. She has no competing
interests to declare.

Author Statement
Professor D’Maris Coffm
interests to declare.

uthor Statement
eressor D'Maris Coffman is the sole author of this manuscript. She has no competing
\end{abstract} interests to declare. 